\title{
Age-associated changes in the ecological niche: implications for mesenchymal stem cell aging
}

\author{
Faizal Z Asumda
}

\begin{abstract}
Adult stem cells are critical for organ-specific regeneration and self-renewal with advancing age. The prospect of being able to reverse tissue-specific post-injury sequelae by harvesting, culturing and transplanting a patient's own stem and progenitor cells is exciting. Mesenchymal stem cells have emerged as a reliable stem cell source for this treatment modality and are currently being tested in numerous ongoing clinical trials. Unfortunately, the fervor over mesenchymal stem cells is mitigated by several lines of evidence suggesting that their efficacy is limited by natural aging. This article discusses the mechanisms and manifestations of age-associated deficiencies in mesenchymal stem cell efficacy. A consideration of recent experimental findings suggests that the ecological niche might be responsible for mesenchymal stem cell aging.
\end{abstract}

\section{Introduction}

Experimentation with mesenchymal stem cells (MSCs) has long moved beyond the pre-clinical phase. MSCs are currently being tested in several ongoing clinical trials for cardiac muscle repair, bone regeneration and joint repair [1-8]. Stem cells are building and regenerative tools; they are fundamental to the body's ability to selfrenew with advancing age [9-15]. Exactly what criteria define the immortality of stem cell lines is variable and is dependent on the goals of individual investigators [16]. The longevity of ex vivo MSCs can be preserved by successively selecting for cell lines with the highest fidelity [16], but the same cannot be done in the whole organism. Time introduces selective and environmental constraints that diminish the fitness of adult stem cells [10-16]. It is increasingly clear that stem cells are subject to the same factors that introduce the genotypic and phenotypic changes associated with "wear and tear" in other somatic cells $[10-12,16]$, but their robust ability to detect and resist damage, and continuously produce progeny with properties akin to parental cells sets them apart $[10,11]$. Of importance is the distinction between replicative and chronological aging [12,17-22]. Stem cells are highly proliferative; adult stem cells in particular have a finite replicative lifespan that is determined to a

Correspondence: Fza06@fsu.edu

Saint James School of Medicine, 1480 Renaissance Drive, Park Ridge, Chicago, IL 60068, USA large degree by telomere attrition $[11,19]$. The growth arrest and resultant cellular senescence displayed after a specific number of population doublings alone [20] are not sufficient to completely compromise stem cell functionality in vivo. They do not correlate directly with the lifespan of the whole organism [21-24]. Ex vivo adult stem cells isolated from aged donors display characteristic features of both chronological and replicative aging. This is typified by the accumulation of damaged macromolecules, and cellular constituents crucial for efficient DNA replication and repair. Other characteristic features are stress-related genome instability, loss of function, and changes in patterns of immunophenotype marker, gene and protein expression [10-16,18-30].

\section{Aging limits the therapeutic potential of mesenchymal stem cells}

Quantitative and qualitative measures of MSC potency define the range of tissue-specific phenotypes into which they can differentiate. Their self-renewing and regenerative ability in vivo correlates directly with the extent of ex vivo proliferative and clonogenic ability. Ex vivo comparison of MSCs isolated from young and aged animals [27-30] and in vitro assessment of isolated MSCs over several population doublings $[31,32]$ are the most utilized experimental aging models. These models are instructive in terms of delineating the extent to which MSCs are subject to the effects of natural aging, but they do not definitively reproduce events of natural aging 
in vivo [21-23]. Results from systems level analyses of this sort force us to confront the reality that MSCs, like other adult stem cells, do not escape the deleterious effects of natural aging. MSCs lose specific aspects of their appeal with natural aging. A key advantage with MSCs is their immediate availability in clinically relevant numbers for acute and long-term therapy. They can be isolated and expanded in vitro in a matter of days $[8,27,29,33]$, but advanced donor age correlates directly with a depleted MSC population [27-29]. This raises questions about their prompt availability in large numbers for autologous transplantation.

The basic but oversimplified understanding of cell therapy is that dead tissue can be repopulated by direct application of exogenous cells. The approach has therefore been two-pronged - direct administration of exogenous MSCs, and reliance on their homing ability to further stimulate endogenous repair. To create viable tissue, transplanted MSCs must survive, engraft and communicate with endogenous cells. Secondary to engraftment and electro-mechanical coupling is transdifferentiation into functional host cells. MSCs lack the level of pluripotency associated with embryonic stem cells (ESCs) but maintain robust clonogenicity and multipotency. They can give rise to adipocytes, chondrocytes, osteoblasts, and cardiomyogenic, neurogenic, and endothelial cells in vitro [8,33-35] (Figure 1). Furthermore, the ability of MSCs to seek out injured tissue is cytokine mediated [29].

Multilineage differentiation, cytokine, paracrine, antiapoptotic and angiogenic capacity is fundamentally age compromised in MSCs [27-30] (Figure 1). Asumda and Chase [27] demonstrated that MSCs derived from aged rats fail to express the adipocyte lipid-binding protein FABP4, osteocalcin, and aggrecan following induction with adipogenic, osteogenic and chondrogenic media, respectively. In contrast, cells derived from young rats display extensive differentiation capacity by forming adipocytes, osteocytes, chondrocytes and cardiomyogenic cells following induction with differentiation media [27] (Figure 1). These specific differentiation and proliferation data from Asumda and Chase [27], further substantiated by $\mathrm{Yu}$ and colleagues [30], demonstrate a fundamental loss of function that, by extension, means MSCs lose the ability to respond effectively to injury $[16,35]$. The issue of electro-mechanical coupling with endogenous cells is further explored by Asumda and Chase [27] under co-culture conditions. They showed that, in comparison to young MSCs, old MSCs express significantly low levels of the gap junction protein connexin-43 [27]. Dye coupling and positive double color staining experiments show that connexin-43 is required for cell-cell gap junctional communication and for electro-mechanical coupling between cardiomyocytes and MSCs [27,36-39]. Despite expressing low levels of connexin-43, old MSCs fused with adjacent ventricular cardiomyocytes and expressed GATA 4, Nkx2.5, cTnI, cTnT and myosin heavy chain [27]. The point must be made here that these co-culture experiments [27] did not investigate functional coupling between MSCs and ventricular cardiomyocytes. Asumda and Chase [27] did not conduct electrophysiological studies, and MSCs were not uncoupled from ventricular myocytes for further determination of the cardiac phenotype. It is not clear, therefore, that aged MSCs acquire an increased differentiation capacity following direct contact with cardiac myocytes. In the absence of this type of assessment, we cannot definitively distinguish stem cell plasticity in terms of transdifferentiation on the part of co-cultured old MSCs as opposed to cell fusion with cardiomyocytes $[39,40]$. The expression of cardiac specific markers in the co-cultured aged MSCs [27] is, in all probability, the result of cell fusion that is the formation of hybrid cells with simultaneous expression of donor and recipient cell markers $[39,40]$. The implication here is that cells isolated from older individuals for therapy might be far too impaired to actively transdifferentiate into contractile cardiac myocytes or organ-specific cells.

In comparison to other candidate stem cells, MSCs possess superior genetic stability. The risk of their spontaneous transformation to cause oncologic issues following transplantation is minimal [41-43]. It is important to take into account the slight interspecies variations. Murine MSCs are fundamentally more genetically unstable when compared to human MSCs [42,44-46] and are significantly more likely to cause oncologic issues. Data from non-human cells can therefore not be extrapolated definitively to humans [46,47]. Age-associated genomic instability is implicated in the spontaneous malignant transformation of ex vivo MSCs [44-49]. So while the evidence for malignant transformation of human MSCs in clinical trials is fiercely questioned and is murky at best [41-43,50-59], the deleterious effects of aging [50] nonetheless present a serious risk factor for in vitro transformation and ectopic tissue formation following transplantation.

MSCs are immune privileged and immunosuppressive; surface immune antigens are present at minimal levels $[8,59,60]$. This unique immunophenotype gives them a selective advantage and is fundamental to their appeal in the clinical setting. T-lymphocyte proliferation is suppressed, immunogenic MHC-Ia expression is marginal, and immunosuppressive MHC-Ib is upregulated [8,60-63]. The effect of natural aging on MSC immunogenicity has not been studied directly and extensively. It is not known, therefore, if MSCs lose their immune privilege properties with advancing age. A consideration of recent experimental findings suggests that MSCs are not intrinsically immunoprivileged [63,64]; they are immunogenic in 
immunocompromised animals [64,65]. This suggests that MSCs require a supportive microenvironment - one with a set and minimal number of factors - to effectively exert their immunoregulatory effects on immune cells [63]. Whether natural aging exacerbates MSC immunogenicity is an open-ended question. It is presumed here that the deleterious effect of aging on the micro-environment will have dire consequences for MSC immune regulation following transplantation. In line with this thinking, the distinction should be made between presumptively compromised allogeneic ex vivo MSCs isolated from aged donors that are inherently immunogenic prior to transplantation, and ex vivo MSCs that either fail to suppress immune cells, and/or elicit an immune response following transplantation due to an age-compromised host microenvironment.

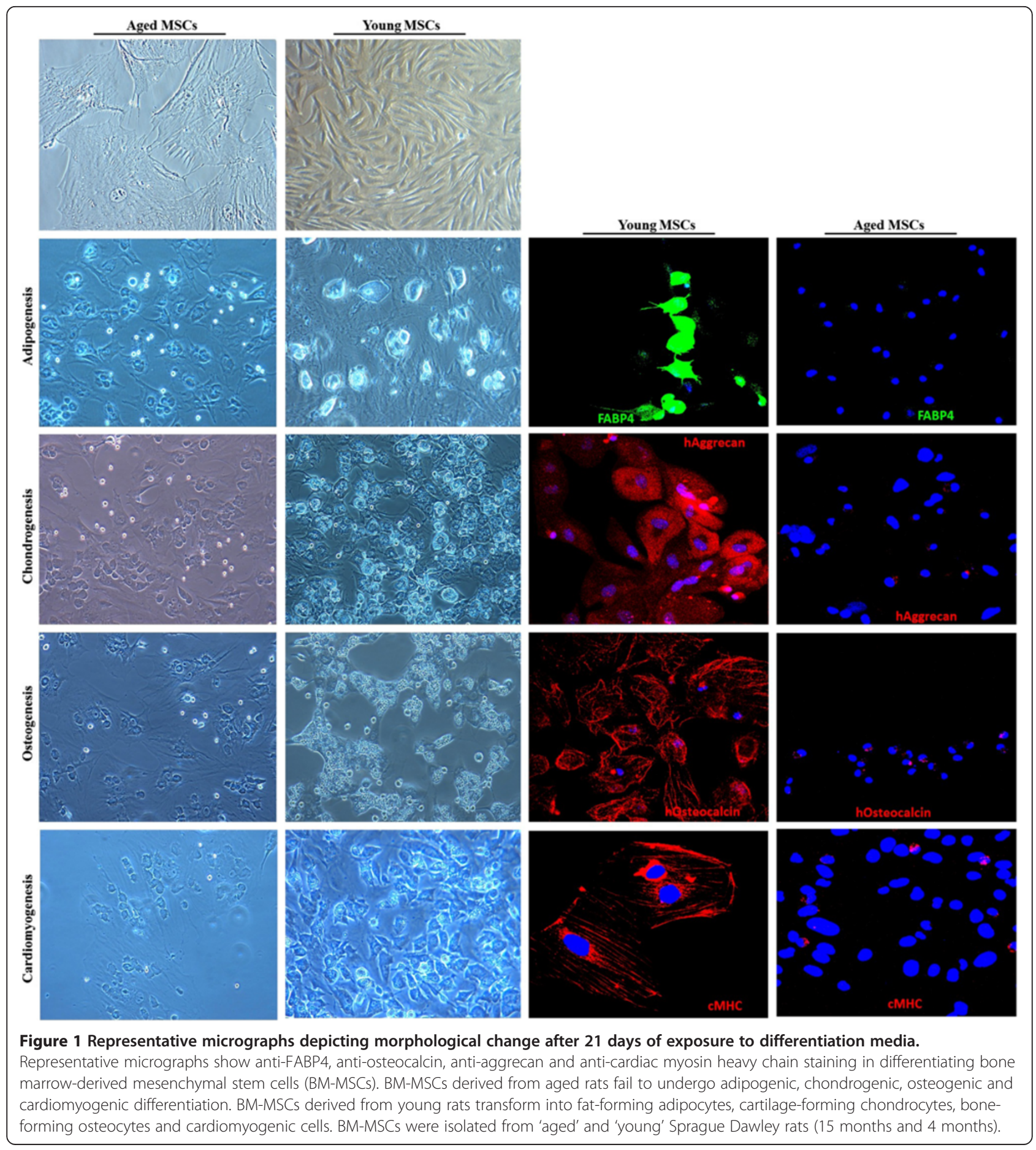




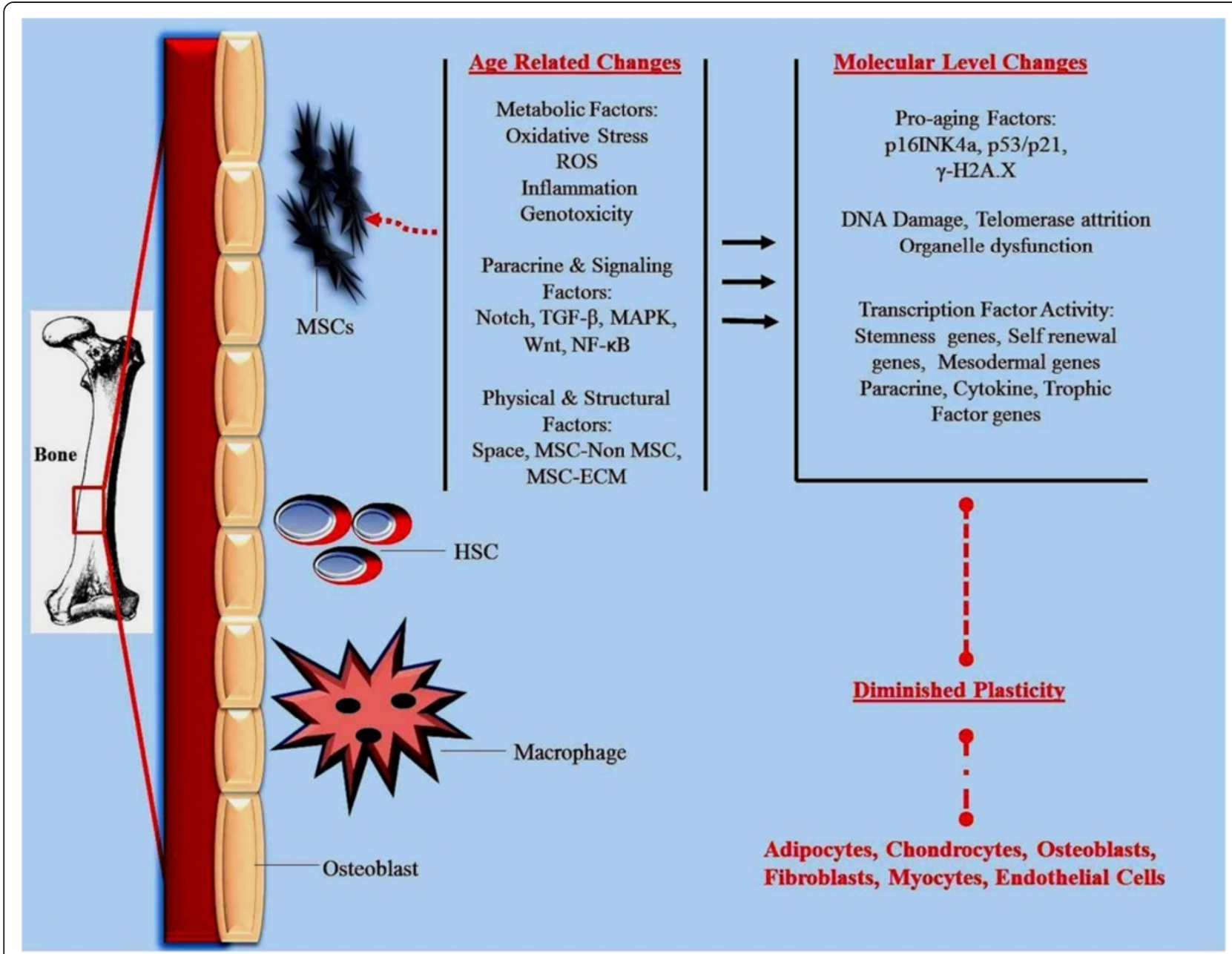

Figure 2 Diagrammatic illustration of potential factors that feed into the bone marrow-derived mesenchymal stem cell (BM-MSC) niche. Diminished BM-MSC function associated with natural aging may be due to deleterious changes at the niche level. Different factors that regulate and maintain the local BM-MSC microenvironment are depicted. Within the niche, BM-MSCs are responsive to metabolic factors and their products, such as oxidative stress and reactive oxygen species (ROS). Paracrine and signaling factors such as Notch, transforming growth factor (TGF)- $\beta$, mitogen-activated protein kinase (MAPK), Wnt and NF-KB are known to be age dysregulated in the stem cell niche. Physical and environmental factors such as space constraints, and cell-cell interactions between BM-MSCs and other stem and non-stem cells resident in the bone marrow, and between BM-MSCs and the local extracellular matrix may undergo age-associated changes. In response to these changes, BMMSCs are likely to undergo molecular level changes, such as increased levels of pro-aging factors, DNA damage, telomerase attrition and transcription factor changes. The direct consequence of these changes is diminished BM-MSC function, self-renewal and differentiation capacity. ECM, extracellular matrix; HSC, hematopoietic stem cell.

Despite the lack of data in direct support of ageassociated intrinsically immunogenic MSCs, the idea is not entirely anecdotal. $\mathrm{Li}$ and colleagues [66] recently demonstrated that extensively passaged MSCs, in addition to displaying characteristic senescence-associated aberrations, lose their immunosuppressive effect on T-cell proliferation. Additionally, MSCs express and rely on toll-like receptors (TLRs) along with Notch signaling to exert Tcell immunomodulatory effects [67]. TLR function [57] and Notch expression [68] are diminished in aged humans. Furthermore, the dysregulation of Notch signaling is associated with the aging phenotype in stem cells [69]. The ultimate test for MSCs in the clinical setting will be their ability to improve quality of life and extend the life of patients; however, for the foreseeable future, the fact that MSCs do not escape the adverse effects of natural aging will be a major limitation for their use in cell therapy.

\section{The ecological niche and mesenchymal stem cell aging}

From a clinical and translational stand point, the aging issue raises a number of questions. The key question is if MSCs from elderly donors fundamentally provide the same healing effect as their younger counterparts? At present, no clinical trial has explicitly tested this 
hypothesis so the answer is not straightforward. A look at past and ongoing phase I to III clinical trials testing the efficacy of MSCs shows an upper age limit up to 90 years [9]. Ex vivo MSCs must be expanded over several population doublings prior to treatment. Extensive passaging diminishes cytoskeleton turnover, and compromises mitochondrial morphology. It also impairs antioxidant capacity, and increases susceptibility towards senescence [70,71]. Geißler and colleagues [70] established that serial in vitro passaging of both young and old MSCs produces molecular alterations independent of chronological in vivo aging. Their data demonstrate that, in addition to the fundamental loss of differentiation capacity, MSC morphology, migration potential, and mitochondrial and cytoskeletal function is impaired over several population doublings [70]. This raises questions about the quality and potency of extensively passaged old MSCs as a therapeutic agent. The issue of donor age can be overcome with allogeneic cells but it presents a potential limitation for autologous therapy [35]. The underlying mechanistic question is if MSCs age intrinsically irrespective of the microenvironment or if the microenvironment is responsible for the aging phenotype? An extension of that question is whether MSCs are genetically programmed [16] like other somatic cells to wilt with time? Or are the observed alterations [27] simply a reaction of the cells to deleterious conditions that arise in their immediate microenvironment [16]?

For the purposes of simplicity, the bone marrow (BM) stem cell niche is examined in this review. Primary explant MSCs isolated from an aged BM compartment at low passage display defects [27] consistent with both replicative and chronological aging; this implicates the niche environment (Figure 2). Specific evidence for this line of thinking is sourced in part from Assmus and colleagues [72]. Their data show that significant changes occur in the BM stem cell niche following acute myocardial infarction that directly affect BM mononuclear cell function [72]. Cells resident in the BM compartment are sensitive and responsive to changes in their niche [72-76]. The niche is in turn responsive to changes in the global systemic milieu [16,77-79]. It is therefore understood that ecological interactions of the BM niche are critical to resident stem cell function [80]. By the same token, the aged tissue microenvironment to which exogenous stem cells are transplanted presents an inhibitory effect $[81,82]$. So while aged ex vivo MSCs might function in a cell autonomous fashion in culture, their interactions with the niche and the microenvironment that they encounter post-transplantation is bidirectional. Alterations in the niche as a consequence of natural aging will, in all probability, affect the survival and integration of transplanted cells.
The dynamic nature of MSC interactions with healthy and injured host cells in the aging microenvironment will, for example, influence their mitotic and differentiation ability. What is unclear at this stage is the degree to which intrinsic factors drive the aging process in MSCs independent of a changing microenvironment. No one single factor has been shown to be responsible for global MSC aging. All the evidence points to the MSC niche environment and the effect that alterations within that micro-milieu has on the cells. This might explain why ex vivo cells from aged donors are compromised at primary isolation [27]; the key seems to lie in prevention. Presumably, the solution is to recreate a microenvironment that is identical to that of young patients. What remains to be determined is factor(s) that can be manipulated to alter the MSC-specific stem cell niche. Perhaps we can learn from studies conducted on nonMSC stem cells. Using the Drosophila testis stem cell niche, Toledano and colleagues [83] demonstrated that increased expression of let-7 accelerates the aging of stem cells by decreasing Imp levels in Drosophila niche cells. Imp regulates $u p d$, which encodes a self-renewal factor; Upd promotes the stemness of adjacent Drosophila niche cells via activation of JAK-STAT signaling [84]. RNA interference-mediated inhibition of Imp in the niche results in reduced Upd levels [83]. The downstream effect of low Upd levels is a diminished number of germ line stem cells in the niche. By specifically targeting Imp expression, Toledano and colleagues [83] were able to rescue the age-associated loss of germ line stem cells. The implication of these results for MSC aging is clear - it suggests that the niche does in fact lose its supportive role with advancing age irrespective of the specific stem cell type. The take-home message here is that we might be able to rescue the age-associated loss in plasticity, and decrease in MSC population. This can be achieved either by preventing the expression of specific factor(s) or blocking the destruction of others [83].

The argument for targeting the micro-milieu is further strengthened by data from Conboy and colleagues [82] and Boyle and colleagues [84]. By exposing satellite cells from old mice to young serum containing specific factors, Conboy and colleagues [82] were able to rescue Notch expression and enhance proliferation in vitro. A translation of these findings to MSCs will suggest that we can reverse the age-associated changes by manipulating the systematic milieu to either increase the presence of anti-aging factors associated with young serum or decrease the levels of deleterious factors associated with aged serum. The details are still being worked out for MSCs and the BM stem cell niche. We do not have a clear picture of definitive MSC-specific anti- or proaging factors to enable the level of mechanistic studies described for muscle and Drosophila stem cells. The 
good news is that most of the signaling factors and pathways already studied in other stem cell types overlap between cells. What we do know is that the BM stem cell niche [72-76] functions as a nest environment. It buttresses MSC viability, stemness, activation, migration, and overall function and protects against cumulative genetic damage [72-76]. The available data suggest that it undergoes fundamental deleterious changes with natural aging that work to diminish MSC function and selfrenewal (Figure 2).

Another recent report by Conboy and colleagues [85] put forward data that demonstrate that ESCs secrete pro-regenerative anti-aging factors that counter the deleterious effects of the aged niche. This piece of information is significant for MSCs because Oct-4+, SSEA-1+, Sca-1+, Lin-CD45- very small embryonic-like stem cells (VSELs) within the BM are age depleted [86,87]. The specific role of VSELs in aging is not well studied; it is presumed here that age-associated changes in VSEL function are consequential for the BM stem cell niche. Their developmental origin [86-89], and the fact that a supportive BM microenvironment is required for their continued fidelity [89], suggests that VSELs are a key contributory component of the BM-derived MSC niche. It has been suggested that VSELs associate with, and play a contributory role to, MSC plasticity $[88,89]$. MSCs are a heterogeneous cell population; their expression of embryonic and pluripotency-associated markers is suggestive of prior contamination by VSELs during primary isolation [88]. Hence, the age-associated collective loss of pluripotency-associated genes by MSCs and other BM stem cells, such as VSELs, multipotent adult progenitor cells and marrow isolated multilineage inducible (MIAMI) cells [88], is suggestive of molecular level sensitivity to aberrant changes in the niche. This line of thinking is consistent with observations made by Asumda and Chase [27] and substantiated by Yew and colleagues [32]. Data from both studies show that ex vivo MSCs from aged rodents [27] and humans [32] show alterations in their expression of stemness and pluripotency-associated genes.

\section{Modifying and targeting specific factors in the niche}

In thinking about what specific anti- or pro-aging factors to target within the BM stem cell niche, the studies by Asumda and Chase [27] and Yew and colleagues [32] are a starting point. The expression of stemness and pluripotency genes is critical for ESC and adult stem self-renewal [75,90,91]. OCT4, SOX2, Rex-1, leukemia inhibitory factor, and fibroblast growth factor are implicated in the maintenance of MSC stemness [75,92]. These are also anti-aging factors that promote MSC function but are age diminished in MSCs [27,32]. The connection between changing conditions within the BM micro-milieu and the inhibition of these factors is not clear. Polycomb complex proteins are known regulators of OCT4, SOX2, and NANOG [75,93,94]. It has been suggested that Polycomb proteins might be involved in the activation and maintenance of OCT4, SOX2, Rex-1 and NANOG in MSCs [75]. Mechanistic studies to determine the association between self-renewal and stemness genes, the BM aging micro-milieu and the aging phenotype in MSCs are justified. Recent data from Han and colleagues [95], for example, show that ageassociated loss of cardiomyogenic differentiation and proliferation ability in MSCs is reversible via forced expression of NANOG alone. They also demonstrate that forced expression of Nanog alone restores transforming growth factor (TGF)- $\beta$ and $553 / \mathrm{p} 21$ signaling in ex vivo aged MSCs [95].

MSCs residing in the BM stem cell niche interact with stem and non-stem cells. They are responsive to the local extracellular matrix and to a host of paracrine and trophic factors $[13,75,80]$ secreted in the local milieu. Notch, TGF- $\beta$, mitogen-activated protein kinase (MAPK) $[73,75]$ and Wnt $[63,71,84]$ signaling are implicated in stem cell aging and specifically in the BM stem cell niche $[15,73,75,76]$. Wnt3a promotes MSC self-renewal by increasing the pool of mesenchymal progenitors, enhancing proliferation and maintaining the undifferentiated state [96]. The drawback to Wnts is that their effect is pleiotropic - in the presence of Wnt3a, MSC osteogenesis is suppressed but Wnt5a promotes alkaline phosphatase expression in MSCs undergoing osteogenesis [96]. The complexity of Wnt protein signaling precludes an outright identification of a single mechanism that links alterations in the BM niche with Wnt and MSC aging. Boland and colleagues [96] postulate that specific spatial or temporal regulation of Wnt signaling and crosstalk with other pathways might boost the progenitor cell pool within which MSCs reside. In their model, canonical Wnts (Wnt3a and Wnt9a) function to maintain the undifferentiated proliferating pool of progenitor BM mononuclear cells [96]. On the other hand, non-canonical Wnts (Wnt5a and Wnt11), which are implicated in MSC osteogenesis and chondrogenesis, will presumably enhance MSC plasticity [96]. This proposed model of in vivo MSC maintenance and differentiation by Wnts has implications for the BM stem cell niche and MSC aging. Zhang and colleagues [97] demonstrated that exposure of MSCs to old rat serum increases reactive oxygen species production and expression of growth inhibitory and pro-aging factors such as p16INK4a, p53/p21 and $\gamma$-H2A.X via the activation of Wnt/ $\beta$-catenin signaling. Zhang and colleagues [98] again showed that Wnt/ $\beta$-catenin signaling directly induces MSC aging by activating reactive oxygen species 
generation in MSCs. It is presumed here that such specific age-associated alterations as a consequence of changes in the ecological niche environment will have consequences [27] (Figure 2) for MSC function and selfrenewal.

Notch-1 expression is diminished in ex vivo MSCs isolated from aged patients [99]. Direct inhibition of Notch-1 results in decreased bone formation [99]; this is suggestive of an age-associated loss in responsiveness to Notch-1 inducers [69]. Cell-cell interactions are crucial for MSC function in the BM stem cell niche [73-76]. Notch receptors are expressed on MSCs, along with their ligands [100]. Notch signaling is highly conserved and controls diverse cellular processes [100]. The link between faulty Notch signaling and aging in stem cells is well established $[10,68,69,82,85]$. Proximity between MSCs and stem, and non-stem cells within the threedimensional BM micro-milieu affect MSC function and self-renewal. The Notch receptor is activated primarily via direct cell-cell contact and is critical for cell-cell communication [100]. Phenotypic and developmental changes in cell proliferation, differentiation and apoptosis are communicated between neighboring cells via Notch signaling. Presumably, age-associated changes in the niche environment will have consequences for Notch signaling and subsequent MSC activity. Studies conducted by Conboy and colleagues [101] show that forced activation of Notch rescues the loss in regenerative potential seen in old muscle. MSCs express all three Notch ligand receptors [100]; it is therefore a legitimate target for reversing age-associated changes in MSC efficacy.

The DNA damage model of aging postulates that aging is a direct result of long-term accumulation of deleterious alterations in DNA structure. The link between DNA damage and aging is well established; MSCs are not exempt in terms of deficient DNA repair. Asumda and Chase [27] demonstrated high levels of the phosphorylated histone $\mathrm{H} 2 \mathrm{~A}$ variant $\gamma-\mathrm{H} 2 \mathrm{~A}$.X in ex vivo aged MSCs. DNA damage accelerates the aging process in rare conditions such as progerias [102-106]. The DNA damage model suggests that deleterious changes in the $\mathrm{BM}$ stem cell niche and genetic determinants of MSC aging are not mutually exclusive events. The response to aberrant environmental changes at the molecular level is genetically determined via an array of signaling networks [107]. For example, impaired DNA damage repair leads to defective replication, transcription and translation events, which result in apoptosis, senescence, and dysfunction [107]. NF-kB is a known central mediator of the cellular response to stress, inflammation and genotoxic insult; with aging, NF- $\mathrm{kB}$ activity is increased [107-109]. The Rel family of transcription factors that constitute NF- $\mathrm{kB}$ regulate a plethora of signaling components and are activated by an array of stimuli. It regulates pro-growth factors involved in promoting the aging phenotype as well as longevity factors [107]. NF$\kappa \mathrm{B}$ is activated in disease models of accelerated aging, but genetic and pharmacologic inhibition of NF- $\mathrm{kB}$ delays the progeroid phenotype, reduces oxidative stress, and retards in vivo and in vitro senescence [110]. Ex vivo MSCs derived from aged mice express high levels of phosphorylated NF-kB [111]. The expression profile of NF-kB differs between old and young MSCs; there are significantly higher levels in the cytoplasm of old MSCs [111]. The NF-kB pathway might be an ideal modulatory and therapeutic factor. By further examining its role in MSC aging, we might be able to tease out and understand the relationship between deleterious changes in the BM micro-milieu, DNA damage and MSC aging.

\section{Conclusion}

Within the context of cell therapy, distinguishing between intrinsic irreversible changes and those that are reversible is vital. Asumda and Chase [27] demonstrated increased DNA damage and lowered telomerase activity as well as altered expression of stemness markers in old MSCs [27]. A similar set of observations were made by Yew and colleagues [32]. BM from older animals was slow to yield plastic-adherent MSC colonies. The resultant old MSCs had a spread out, flat, enlarged morphology with nuclei that appear larger than normal [27]. This phenotype is reminiscent of extensively passaged MSCs [27]; Yu and colleagues [30] made similar observations. The former set of observations (DNA damage, stemness genes, telomerase activity) is an aspect of intrinsic aging. This is otherwise unavoidable in non-stem tissue cells due to increasing, and cumulative use of specific signaling pathways over time [82]. The latter set of observations (morphology) is characteristic of physical and molecular level deterioration in response to adverse external changes. Asumda and Chase [27] assessed MSCs at low passage immediately following primary isolation. When taken together, these data indicate that specific age-associated cell-extrinsic changes occur in the BM compartment that directly influence component cells by altering cell-intrinsic factors [16] (Figure 2). Presumably, deleterious changes that occur in the stem cell milieu under pathological conditions should accelerate the aging process in chronologically young individuals so that the same defects observed in cells derived from aged donors are evident in cells derived from young but diseased donors [103,104]. For example, the differentiation capacity and efficacy of MSCs derived from donors suffering from Hutchinson-Gilford progeria syndrome (a premature aging disease in which uncharacteristically accelerated aging is observed in children) is significantly compromised $[105,106]$. We do not have to directly test 
in humans if age-compromised MSCs elicit healing effects akin to cells from younger donors. It is possible to deduce an answer based on the responsiveness of Hutchinson-Gifford progeria patients to autologous therapy [106].

The decline in MSC function is typified by an inability to repair injury, and proliferate or differentiate into multiple lineages. If the observed defects [27] are a consequence of deleterious changes in the microenvironment, then the problem might be easily fixable - by exposure to a young unperturbed microenvironment [82]. It can also be fixed by modulating specific pro- and anti-aging factors in the BM micro-milieu. This will involve identification of the specific supportive factors within the BM stem cell microenvironment that are lost or compromised with age and making adjustments. It may also involve transplantation and introduction of niche components into host tissue along with transplanted cells. Conversely, if the defects are solely cell autonomous and intrinsic, development of countermeasures will require a more detailed understanding of underlying mechanisms. This will be followed by pharmacologic and molecular level manipulation of aged ex vivo MSCs in an in vitro system [32,95]. This can be done prior to transplantation for cases where autologous cells are preferred and absolutely necessary. Alternatively, the in vivo BM niche environment can be experimentally targeted to understand how and why aging compromises the efficacy of MSCs. Interactions within the in vivo BM stem cell niche can also be reproduced outside the body to quantify the specific age-associated changes. The ultimate goal will be to manipulate it in the whole organism and halt the age-associated loss of function in MSCs. The report by Asumda and Chase [27] along with a number other recent reports $[28,29]$ demonstrate a definitive association between donor age and defective MSC function. Their specific data set the stage for more mechanistic studies $[97,98]$ detailing a causal role for the niche environment along with counter measures [89] to reverse the loss of function. Clearly, MSCs lose their regenerative potential as a result of natural aging. The perspective presented here is that the aging niche and consequent deleterious changes that occur in this microenvironment might be the main culprit in MSC aging. The key therefore to overcoming the aging issue in MSC-mediated cell therapy is unlocking and furthering the current understanding of the specific microenvironmental factors that compromise MSCs over time.

\section{Abbreviations}

BM: Bone marrow; ESC: Embryonic stem cell; MSC: Mesenchymal stem cell; NF-kB: Nuclear factor kB; TGF: Transforming growth factor; TLR: Toll-like receptors; VSEL: Very small embryonic like stem cell.

\section{Competing interests}

The author declares that they have no competing interests.

\section{Acknowledgements}

I sincerely thank Dr Bryant Chase for supporting my research during my time at Florida State University. Data and information from [35] reproduced in part with permission from LAP Lambert Academic Publishing and in accordance with the LAP Lambert Academic Publishing Copyright agreement and Authors' Rights and Responsibilities.

Published: 14 May 2013

\section{References}

1. Traverse JH, Henry TD, Pepine CJ, Willerson JT, Zhao DX, Ellis SG, Forder JR, Anderson RD, Hatzopoulos AK, Penn MS, Perin EC, Chambers J, Baran KW, Raveendran G, Lambert C, Lerman A, Simon DI, Vaughan DE, Lai D, Gee AP, Taylor DA, Cogle CR, Thomas JD, Olson RE, Bowman S, Francescon J, Geither C, Handberg E, Kappenman C, Westbrook L, et al: Effect of the use and timing of bone marrow mononuclear cell delivery on left ventricular function after acute myocardial infarction: the TIME randomized trial. JAMA 2012, 308:2380-2389.

2. Hare JM, Fishman JE, Gerstenblith G, DiFede Velazquez DL, Zambrano JP, Suncion VY, Tracy M, Ghersin E, Johnston PV, Brinker JA, Breton E, DavisSproul J, Schulman IH, Byrnes J, Mendizabal AM, Lowery MH, Rouy D, Altman P, Wong Po Foo C, Ruiz P, Amador A, Da Silva J, McNiece IK, Heldman A: Comparison of allogeneic vs autologous bone marrowderived mesenchymal stem cells delivered by transendocardial injection in patients with ischemic cardiomyopathy: the POSEIDON randomized trial. JAMA 2012, 308:2369-2379.

3. Traverse JH, Henry TD, Vaughan DE, Ellis SG, Pepine CJ, Willerson JT, Zhao DX, Simpson LM, Penn MS, Byrne BJ, Perin EC, Gee AP, Hatzopoulos AK, McKenna DH, Forder JR, Taylor DA, Cogle CR, Baraniuk S, Olson RE, Jorgenson BC, Sayre SL, Vojvodic RW, Gordon DJ, Skarlatos SI, Moyè LA, Simari RD, Cardiovascular Cell Therapy Research Network: Late TIME: a phase-Il, randomized, double-blinded, placebo-controlled, pilot trial evaluating the safety and effect of administration of bone marrow mononuclear cells 2 to 3 weeks after acute myocardial infarction. Tex Heart Inst J 2010, 37:412-420.

4. Ishizaka S, Horie N, Satoh K, Fukuda Y, Nishida N, Nagata I: Intra-arterial cell transplantation provides timing-dependent cell distribution and functional recovery after stroke. Stroke 2013, 44:720-726.

5. Weiss DJ, Casaburi R, Flannery R, Leroux-Williams M, Tashkin DP: A placebocontrolled randomized trial of mesenchymal stem cells in chronic obstructive pulmonary disease. Chest 2012. Epub ahead of print.

6. Diekman BO, Wu CL, Louer CR, Furman BD, Huebner JL, Kraus VB, Olson SA, Guilak F: Intra-articular delivery of purified mesenchymal stem cells from C57BL/6 or MRL/MpJ superhealer mice prevents post-traumatic arthritis. Cell Transplant 2012. Epub ahead of print.

7. Otsuru S, Gordon PL, Shimono K, Jethva R, Marino R, Phillips CL, Hofmann TJ, Veronesi E, Dominici M, Iwamoto M, Horwitz EM: Transplanted bone marrow mononuclear cells and MSCs impart clinical benefit to children with Osteogenesis imperfect through different mechanisms. Blood 2012, 120:1933-1941.

8. Williams AR, Hare JM: Mesenchymal stem cells: biology, pathophysiology, translational findings, and therapeutic implications for cardiac disease. Circ Res 2011, 109:923-940.

9. ClinicalTrials.gov. http://www.clinicaltrials.gov/.

10. Conboy IM, Rando TA: Aging, stem cells and tissue regeneration: lessons from muscle. Cell Cycle 2005, 4:407-410.

11. Liu L, Rando TA: Manifestations and mechanisms of stem cell aging. I Cell Biol 2011, 193:257-266

12. Lepperdinger $\mathrm{G}$ : Open-ended question: is immortality exclusively inherent to the germline? Gerontology 2009, 55:114-117.

13. Lepperdinger G: Developmental programs are kept alive during adulthood by stem cells: The aging aspect. Exp Gerontol 2012. Epub ahead of print

14. Symonds CE, Galderisi U, Giordano A: Aging of the inceptive cellular population: the relationship between stem cells and aging. Aging 2009, 1:372-381

15. Pollina EA, Brunet A: Epigenetic regulation of aging stem cells. Oncogene 2011, 30:3105-3126

16. Rando T: Stem cells, ageing and the quest for immortality. Nature 2006, 441:1080-1086. 
17. Siminovitch L, Till JE, McCulloch EA: Decline in colony-forming ability of marrow cells subjected to serial transplantation into irradiated mice. $J$ Cell Physiol 1964, 64:23

18. Waterstrat A, Van Zant G: Effects of aging on hematopoietic stem and progenitor cells. Curr Opin Immunol 2009, 21:408-413.

19. Wright WE, Shay JW: Historical claims and current interpretations of replicative aging. Nat Biotechnol 2002, 20:682-688.

20. Hayflick L, Moorhead P: The serial cultivation of human diploid cell strains. Exp Cell Res 1961, 25:585-621.

21. Rubin $\mathrm{H}$ : The disparity between human cell senescence in vitro and lifelong replication in vivo. Nat Biotechnol 2002, 20:675-681.

22. Rubin H: Cell aging in vivo and in vitro. Mech Ageing Dev 1997, 98:1-35.

23. Cameron IL: Minimum number of cell doublings in an epithelial cell population during the lifespan of the mouse. J Gerontol 1972, 27:157-161.

24. Cameron IL: Cell proliferation and renewal in aging mice. J Gerontol 1972, 27:162-172.

25. Burhans WC, Weinberger M: DNA replication stress, genome instability and aging. Nucleic Acids Res 2007, 35:7545-7556.

26. Burtner CR, Murakami CJ, Kennedy BK, Kaeberlein M: A molecular mechanism of chronological aging in yeast. Cell Cycle 2009, 8:1256-1270

27. Asumda FZ, Chase PB: Age-related changes in rat bone-marrow mesenchymal stem cell plasticity. BMC Cell Biol 2012, 12:44.

28. Choudhery MS, Khan M, Mahmood R, Mehmood A, Khan SN, Riazuddin S: Bone marrow derived mesenchymal stem cells from aged mice have reduced wound healing, angiogenesis, proliferation and anti-apoptosis capabilities. Cell Biol Int 2012, 36:747-753.

29. Alt EU, Senst C, Murthy SN, Slakey DP, Dupin CL, Chaffin AE, Kadowitz PJ, Izadpanah R: Aging alters tissue resident mesenchymal stem cell properties. Stem Cell Res 2012, 8:215-225.

30. Yu J, Wu X, Gimble J, Guan X, Freitas M, Bunnell B: Age-related changes in mesenchymal stem cells derived from rhesus macaque bone marrow. Aging Cell 2011, 10:66-79.

31. Bonab MM, Alimoghaddam K, Talebian F, Ghaffari SH, Ghavamzadeh A Nikbin B: Aging of mesenchymal stem cell in vitro. BMC Cell Biol 2006, $7: 1-7$

32. Yew T, Chiu F, Tsai C, Chen H, Lee W, Chen YJ, Chang MC, Hung SC: Knockdown of p21Cip1/Waf1 enhances proliferation, the expression of stemness markers, and osteogenic potential in human mesenchymal stem cells. Aging Cell 2011, 10:1-13.

33. Asumda FZ, Chase PB: Nuclear cardiac troponin and tropomyosin are expressed early in cardiac differentiation of rat mesenchymal stem cells. Differentiation 2012, 83:106-115.

34. Pittenger MF, Mackay AM, Beck SC, Jaiswal RK, Douglas R, Mosca JD, Moorman MA, Simonetti DW, Craig S, Marshak DR: Multilineage potential of adult human mesenchymal stem cells. Science 1999, 284:143-147.

35. Asumda F: Mesenchymal stem cell aging: implications for cellular cardiomyoplasty: a theoretical exposition. Saarbrücken: LAP Lambert Academic Publishing AG \& Co. KG; 2012

36. Valiunas V, Doronin S, Valiuniene L, Potapova I, Zuckerman J, Walcott B, Robinson RB, Rosen MR, Brink PR, Cohen IS: Human mesenchymal stem cells make cardiac connexins and form functional gap junctions. J Physiol 2004, 555:617-626.

37. Pijnappels DA, Schalij MJ, Ramkisoensing AA, van Tuyn J, de Vries AAF, van der Laarse A, Ypey DL, Atsma DE: Forced alignment of mesenchymal stem cells undergoing cardiomyogenic differentiation affects functional integration with cardiomyocyte cultures. Circ Res 2008, 103:167-176.

38. Rastan AJ, Walther T, Kostelka M, Garbade J, Schubert A, Stein A, Dhein S, Mohr FW: Morphological, electrophysiological and coupling characteristic of bone morrow-derived mononuclear cells - an in vitro model. Eur J Cardiothorac Surg 2004, 78:1989-1993.

39. Garbade J, Shubert A, Ardawan JR, Lenz D, Walther T, Gummert JF, Dhein S, Mohr F-W: Fusion of bone marrow-derived stem cells with cardiomyocytes in a heterologous in vitro model. Eur J Cardiothorac Surg 2005, 28:685-691.

40. Wurmser AE, Gage FH: Stem cells: cell fusion causes confusion. Nature 2002, 416:485-487.

41. Hatzistergos KE, Blum A, Ince TA, Grichnik JM, Hare JM: What is the oncologic risk of stem cell treatment for heart disease? Circ Res 2011. 108:1300-1303.

42. Bernardo ME, Zaffaroni N, Novara F, Cometa AM, Avanzini MA, Moretta A, Montagna D, Maccario R, Villa R, Daidone MG, Zuffardi O, Locatelli F:
Human bone marrow derived mesenchymal stem cells do not undergo transformation after long-term in vitro culture and do not exhibit telomere maintenance mechanisms. Cancer Res 2007, 67:9142-9149.

43. Lazennec $\mathrm{G}$, Jorgensen C: Adult multipotent stromal cells and cancer: risk or benefit? Stem Cells 2008, 26:1387-1394

44. Li H, Fan X, Kovi RC, Jo Y, Moquin B, Konz R, Stoicov C, Kurt-Jones E, Grossman SR, Lyle S, Rogers AB, Montrose M, Houghton J: Spontaneous expression of embryonic factors and p53 point mutations in aged mesenchymal stem cells: a model of age-related tumorigenesis in mice. Cancer Res 2007, 67:1089-1098.

45. Miura M, Miura Y, Padilla-Nash HM, Molinolo AA, Fu B, Patel V, Seo BM, Sonoyama W, Zheng JJ, Baker CC, Chen W, Ried T, Shi S: Accumulated chromosomal instability in murine bone marrow mesenchymal stem cells leads to malignant transformation. Stem Cells 2006, 24:1095-1103.

46. Torsvik A, Røsland GV, Bjerkvig R: Comment to: 'Spontaneous transformation of adult mesenchymal stem cells from cynomolgus macaques in vitro' by Z. Ren and colleagues. Exp. Cell Res 2011, 317:29502957. spontaneous transformation of mesenchymal stem cells in culture: facts or fiction? Exp Cell Res 2012, 318:441-443.

47. Ren Z, Zhang YA, Chen Z: Spontaneous transformation of cynomolgus mesenchymal stem cells in vitro: further confirmation by short tandem repeat analysis. Exp Cell Res 2012, 318:435-444.

48. Ren Z, Wang J, Zhu W, Guan Y, Zou C, Chen Z, Zhang YA: Spontaneous transformation of adult mesenchymal stem cells from cynomolgus macaques in vitro. Exp Cell Res 2011, 317:2950-2957.

49. Røsland GV, Svendsen A, Torsvik A, Sobala E, McCormack E, Immervoll H, Mysliwietz J, Tonn JC, Goldbrunner R, Lonning PE, Bjerkvig R, Schichor C: Long-term cultures of bone marrow-derived human mesenchymal stem cells frequently undergo spontaneous malignant transformation. Cancer Res 2009, 69:5331-5339.

50. Mimeault M, Batra SK: Recent insights into the molecular mechanisms involved in aging and the malignant transformation of adult stem/progenitor cells and their therapeutic implications. Ageing Res Rev 2009, 8:94-112.

51. de la Fuente R, Bernad A, Garcia-Castro J, Martin MC, Cigudosa JC: Retraction: spontaneous human adult stem cell transformation. Cancer Res 2010, 15:6682.

52. Torsvik A, Røsland GV, Svendsen A, Molven A, Immervoll H, McCormack E, Lønning PE, Primon M, Sobala E, Tonn JC, Goldbrunner R, Schichor C, Mysliwietz J, Lah TT, Motaln H, Knappskog S, Bjerkvig R: Spontaneous malignant transformation of human mesenchymal stem cells reflects cross-contamination: putting the research field on track. Cancer Res 2010, 70:6393-6396

53. Jeong JO, Han JW, Kim JM, Cho HJ, Park C, Lee N, Kim DW, Yoon YS: Malignant tumor formation after transplantation of short-term cultured bone marrow mesenchymal stem cells in experimental myocardial infarction and diabetic neuropathy. Circ Res 2011, 108:1340-1347.

54. Tarte K, Gaillard J, Lataillade JJ, Fouillard L, Becker M, Mossafa H, Tchirkov A, Rouard H, Henry C, Splingard M, Dulong J, Monnier D, Gourmelon P, Gorin NC, Sensebe L: Clinical-grade production of human mesenchymal stromal cells: occurrence of aneuploidy without transformation. Blood 2010, 115:1549-1553.

55. Nauta AJ, Osborn MJ, Panoskaltsis Mortari A, McElmurry RT, Bell S, Xia L, Zhou N, Riddle M, Schroeder TM, Westendorf JJ, Mclvor RS, Hogendoorn PC, Szuhai K, Oseth L, Hirsch B, Yant SR, Kay MA, Peister A, Prockop DJ, Fibbe WE, Blazar BR: Sarcoma derived from cultured mesenchymal stem cells. Stem Cells 2007, 25:371-379.

56. Wong RS: Mesenchymal stem cells: angels or demons? J Biomed Biotechnol 2011, 2011:459510.

57. Kassem M, Burns JS, García Castro J, Rubio Muñoz D: Adult stem cells and cancer. Cancer Res 2005, 65:9601.

58. Fazel SS, Angoulvant D, Butany J, Weisel RD, Li RK: Mesenchymal stem cells engineered to overexpress stem cell factor improve cardiac function but have malignant potential. J Thorac Cardiovasc Surg 2008, 136:1388-1399.

59. Bernardo ME, Fibbe WE: Safety and efficacy of mesenchymal stromal cell therapy in autoimmune disorders. Ann NY Acad Sci 2012, 1266:107-117.

60. Dhingra S, Huang XP, Li RK: Challenges in allogeneic mesenchymal stem cell-mediated cardiac repair. Trends Cardiovasc Med 2010, 20:263-268.

61. Di Nicola M, Carlo-Stella C, Magni M, Milanesi M, Longoni PD, Matterucci P, Grisanti S, Gianni AM: Human bone marrow stromal cells suppress Tlymphocyte proliferation induced by cellular or nonspecific mitogenic stimuli. Blood 2002, 99:838-843. 
62. Bartholomew A, Sturgeon C, Siatskas M, Ferrer K, Mclntosh K, Patil S, Hardy W, Devine S, Ucker D, Deans R, Moseley A, Hoffman R: Mesenchymal stem cells suppress lymphocyte proliferation in vitro and prolong skin graft survival in vivo. Exp Hematol 2002, 30:42-48.

63. Uccelli A, Moretta L, Pistoia V: Mesenchymal stem cells in health and disease. Nat Rev Immuno 2008, 8:726-736.

64. Nauta AJ, Westerhuis G, Kruisselbrink AB, Lurvink EG, Willemze R, Fibbe WE: Donor-derived mesenchymal stem cells are immunogenic in an allogeneic host and stimulate donor graft rejection in a nonmyeloablative setting. Blood 2006, 108:2114-2120.

65. Eliopoulos N, Stagg J, Lejeune L, Pommey S, Galipeau J: Allogeneic marrow stromal cells are immune rejected by MHC class I and II mismatched recipient mice. Blood 2005, 106:4057-4065.

66. $L i X Y$, Ding J, Zheng $Z H, L i X Y, W u Z B$, Zhu P: Long-term culture in vitro impairs the immunosuppressive activity of mesenchymal stem cells on $T$ cells. Mol Med Report 2012, 6:1183-1189.

67. Liotta F, Angeli R, Cosmi L, Fili L, Manuelli C, Frodali F, Mazzinghi B, Maggi L, Pasini A, Lisi V, Santarlasci V, Consoloni L, Angelotti ML, Romagnani P, Parronchi P, Krampera M, Maggi E, Romagnani S, Annunziato F: Toll-like receptors 3 and 4 are expressed by human bone marrow-derived mesenchymal stem cells and can inhibit their T-cell modulatory activity by impairing Notch signaling. Stem Cells 2008, 26:279-289.

68. Carey KA, Farnfield MM, Tarquinio SD, Cameron-Smith D: Impaired expression of Notch signaling genes in aged human skeletal muscle. $J$ Gerontol A Biol Sci Med Sci 2007, 62:9-17.

69. Stolzing A, Sethe S: Watch your notch: a link between aging and stem cell fate? Rejuvenation Res 2004, 7:9-11.

70. Geißler S, Textor M, Kühnisch J, Könnig D, Klein O, Ode A, Pfitzner T, Adjaye J, Kasper G, Duda GN: Functional comparison of chronological and in vitro aging: differential role of the cytoskeleton and mitochondria in mesenchymal stromal cells. PLoS One 2012, 7:e52700.

71. Kilpinen L, Tigistu-Sahle F, Oja S, Greco D, Parmar A, Saavalainen P, Nikkilä J, Korhonen M, Lehenkari $P$, Käkelä R, Laitinen S: Aging bone marrow mesenchymal stromal cells have altered membrane glycerophospholid composition and functionality. J Lipid Res 2013, 54:622-635.

72. Assmus B, Iwasaki M, Schächinger V, Roexe T, Koyanagi M, lekushi K, Xu Q, Tonn T, Seifried E, Liebner S, Kranert WT, Grünwald F, Dimmeler S, Zeiher AM: Acute myocardial infarction activates progenitor cells and increases Wnt signalling in the bone marrow. Eur Heart J 2012, 33:1911-1919.

73. Méndez-Ferrer S, Michurina TV, Ferraro F, Mazloom AR, Macarthur BD, Lira SA, Scadden DT: Mesenchymal and haematopoietic stem cells form a unique bone marrow niche. Nature 2010, 466:829-834.

74. Chow A, Lucas D, Hidalgo A, Méndez-Ferrer S, Hashimoto D, Scheiermann C, Battista M, Leboeuf M, Prophete C, van Rooijen N, Tanaka M, Merad M, Frenette PS: Bone marrow CD169+ macrophages promote the retention of hematopoietic stem and progenitor cells in the mesenchymal stem cell niche. J Exp Med 2011, 208:261-271.

75. Kolf CM, Cho E, Tuan RS: Mesenchymal stromal cells. Biology of adult mesenchymal stem cells: regulation of niche, self-renewal and differentiation. Arthritis Res Ther 2007, 9:204.

76. Ehninger A, Trumpp A: The bone marrow stem cell niche grows up: mesenchymal stem cells and macrophages move in. J Exp Med 2011, 208:421-428.

77. Sharpless NE, DePinho RA: How stem cells age and why this makes us grow old. Nat Rev Mol Cell Biol 2007, 8:703-713.

78. Scadden DT: The stem-cell niche as an entity of action. Nature 2006, 441:1075-1079.

79. Spradling A, Drummond-barbosa D, Kai T: Stem cells find their niche. Nature 2001, 414:98-104

80. Jones DL, Wagers AJ: No place like home: anatomy and function of the stem cell niche. Nat Rev Mol Cell Biol 2008, 9:11-21.

81. Lavasani M, Robinson AR, Lu A, Song M, Feduska JM, Ahani B, Tilstra JS, Feldman CH, Robbins PD, Niedernhofer LJ, Huard J: Muscle-derived stem/ progenitor cell dysfunction limits healthspan and lifespan in a murine progeria model. Nat Commun 2012, 3:608.

82. Conboy IM, Conboy MJ, Wagers AJ, Girma ER, Weissman IL, Rando TA: Rejuvenation of aged progenitor cells by exposure to a young systemic environment. Nature 2005, 433:760-764.

83. Toledano H, D'Alterio C, Czech B, Levine E, Jones DL: The let-7-Imp axis regulates ageing of the Drosophila testis stem-cell niche. Nature 2012, 485:605-610.
84. Boyle M, Wong C, Rocha M, Jones DL: Decline in self-renewal factors contributes to aging of the stem cell niche in the Drosophila testis. Cell Stem Cell 2007, 1:470-478.

85. Conboy IM, Yousef H, Conboy MJ: Embryonic anti-aging niche. Aging 2011, 3:555-563

86. Ratajczak MZ, Shin DM, Ratajczak J, Kucia M, Bartke A: A novel insight into aging: are the pluripotent very small embryonic-like stem cells (VSELs) in adult tissues overtime depleted in an lgf-1-dependent manner? Aging 2010, 2:875-883.

87. Zuba-Surma EK, Wu W, Ratajczak J, Kucia M, Ratajczak MZ: Very small embryonic-like stem cells in adult tissues-potential implications for aging. Mech Ageing Dev 2009, 130:58-66.

88. Ratajczak MZ, Machalinski B, Wojakowski W, Ratajczak J, Kucia M: A hypothesis for an embryonic origin of pluripotent Oct-4(+) stem cells in adult bone marrow and other tissues. Leukemia 2007, 21:860-867.

89. Anjos-Afonso F, Bonnet D: Non-hematopoietic/endothelial SSEA-1 pos cells defines the most primitive progenitors in the adult murine bone marrow mesenchymal compartment. Blood 2007, 109:1298-1306.

90. Greco SJ, Liu K, Rameshwar P: Functional similarities among genes regulated by Oct4 in human mesenchymal and embryonic stem cells. Stem Cells 2007, 25:3143-3154.

91. Gonzalez R, Maki CB, Pacchiarotti J, Csontos S, Pham JK, Slepko N, Patel A, Silva F: Pluripotent marker expression and differentiation of human second trimester mesenchymal stem cells. Biochem Biophy Res Comm 2007, 362:491-497.

92. Tsutsumi S, Shimazu A, Miyazaki K, Pan H, Koike C, Yoshida E, Takagishi K, Kato $Y$ : Retention of multilineage differentiation potential of mesenchymal cells during proliferation in response to FGF. Biochem Biophys Res Commun 2001, 288:413-419.

93. Boyer LA, Plath K, Zeitlinger J, Brambrink T, Medeiros LA, Lee TI, Levine SS, Wernig M, Tajonar A, Ray MK, Bell GW, Otte AP, Vidal M, Gifford DK, Young $\mathrm{RA}$, Jaenisch R: Polycomb complexes repress developmental regulators in murine embryonic stem cells. Nature 2006, 441:349-353.

94. Ringrose L, Paro R: Epigenetic regulation of cellular memory by the polycomb and trithorax group proteins. Annu Rev Genet 2004, 38:413-443.

95. Han J, Mistriotis P, Lei P, Wang D, Liu S, Andreadis ST: Nanog reverses the effects of organismal aging on mesenchymal stem cell proliferation and myogenic differentiation potential. Stem Cells 2012, 30:2746-2759.

96. Boland GM, Perkins G, Hall DJ, Tuan RS: Wnt 3a promotes proliferation and suppresses osteogenic differentiation of adult human mesenchymal stem cells. J Cell Biochem 2004, 93:1210-1230.

97. Zhang DY, Wang HJ, Tan YZ: Wnt/b-catenin signaling induces the aging of mesenchymal stem cells through the DNA damage response and the p53/p21 pathway. PLoS One 2011, 6:e21397.

98. Zhang DY, Pan Y, Zhang C, Yan BX, Yu SS, Wu DL, Shi MM, Shi K, Cai XX, Zhou SS, Wang JB, Pan JP, Zhang LH: Wnt/ $\beta$-catenin signaling induces the aging of mesenchymal stem cells through promoting the ROS production. Mol Cell Biochem 2013, 374:13-20.

99. Stolzing A, Jones E, McGonagle D, Scutt A: Age-related changes in human bone marrow-derived mesenchymal stem cells: consequences for cell therapies. Mech Ageing Dev 2008, 129:163-173.

100. Oldershaw R, Murdoch A, Brennan K, Hardingham T: The putative role of the notch ligand, jagged 1 , in the mediation of early events of human mesenchymal stem cell chondrogenesis. Int J Exp Pathol 2005, 86:A47.

101. Conboy IM, Conboy MJ, Smythe GM, Rando TA: Notch-mediated restoration of regenerative potential to aged muscle. Science 2003, 302:1575-1577.

102. Garinis GA, van der Horst GT, Vijg J, Hoeijmakers JH: DNA damage and ageing: new-age ideas for an age-old problem. Nat Cell Biol 2008, 10:1241-1247.

103. Niedernhofer $\sqcup$, Glorioso JC, Robbins PD: Dedifferentiation rescues senescence of progeria cells but only while pluripotent. Stem Cell Res Ther 2011, 2:28.

104. Liu GH, Barkho BZ, Ruiz S, Diep D, Qu J, Yang SL, Panopoulos AD, Suzuki K, Kurian L, Walsh C, Thompson J, Boue S, Fung HL, Sancho-Martinez I, Zhang K, Yates J, Izpisua Belmonte JC: Recapitulation of premature ageing with iPSCs from Hutchinson-Gilford progeria syndrome. Nature 2011, 472:221-225.

105. di Scaffi P, Misteli T: Lamin A-dependent misregulation of adult stem cells associated with accelerated ageing. Nat Cell Biol 2008, 10:452-459.

106. Zhang J, Lian Q, Zhu G, Zhou F, Sui L, Tan C, Mutalif RA, Navasankari R, Zhang Y, Tse HF, Stewart CL, Colman A: A human iPSC model of 
Hutchinson Gilford progeria reveals vascular smooth muscle and mesenchymal stem cell defects. Cell Stem Cell 2011, 8:31-45.

107. Tilstra JS, Clauson CL, Niedernhofer L, Robbins PD: NF-KB in aging and disease. Aging Dis 2011, 2:449-465.

108. Chen Q, Liu K, Robinson AR, Clauson CL, Blair HC, Robbins PD, Niedernhofer $\sqcup$, Ouyang H: DNA damage drives accelerated bone aging via an NF-KBdependent mechanism. J Bone Miner Res 2012. Epub ahead of print.

109. Le Couteur DG, Handelsman DJ: DNA damage, NK-KB and accelerated aging. Asian J Androl 2012, 14:811-812.

110. Tilstra JS, Robinson AR, Wang J, Gregg SQ, Clauson CL, Reay DP, Nasto LA, St Croix CM, Usas A, Vo N, Huard J, Clemens PR, Stolz DB, Guttridge DC, Watkins SC, Garinis GA, Wang Y: NF-kB inhibition delays DNA damageinduced senescence and aging in mice. J Clin Invest 2012, 122:2601-2612.

111. Pandey AC, Semon JA, Kaushal D, O'Sullivan RP, Glowacki J, Gimble JM, Bunnell BA: MicroRNA profiling reveals age-dependent differential expression of nuclear factor $\mathrm{KB}$ and mitogen-activated protein kinase in adipose and bone marrow-derived human mesenchymal stem cells. Stem Cell Res Ther 2011, 2:49.

doi:10.1186/scrt197

Cite this article as: Asumda: Age-associated changes in the ecological niche: implications for mesenchymal stem cell aging. Stem Cell Research \& Therapy 2013 4:47. 